\title{
Studi Transpor Sedimen di Perairan Muara Sungai Bodri, Kabupaten Kendal
}

\author{
Dayinta Andayani1*, Agus Anugroho Dwi Suryoputro ${ }^{1}$, Warsito Atmodjo ${ }^{1}$, Alfi Satriadi ${ }^{1}$, \\ dan Petrus Subardjo ${ }^{1}$ \\ Departemen Oseanografi, Fakultas Perikanan dan Ilmu Kelautan., Universitas Diponegoro \\ Jl. Prof. H. Soedharto, SH,Tembalan, Kota Semarang, KodePos 50275 \\ Email:dayinta.andayani@gmail.com
}

\begin{abstract}
Abstrak
Pantai akan terus berubah bentuknya menyesuaikan kondisi keseimbangan dinamiknya, proses tersebut dapat mengakibatkan akresi ataupun abrasi. Bentuk morfologi pantai yang terus berubah juga terjadi di perairan muara sungai Bodri. Hal ini tidak lepas dari pengaruh gelombang, arus sejajar pantai dan pergerakan sedimen. Perubahan tersebut akan berpengaruh terhadap aktivitas penduduk terutama nelayan yang kesulitan keluar masuk muara sungai Bodri. Tujuan penelitian ini adalah untuk mengetahui transpor sedimen yang disebabkan oleh arus sejajar pantai di perairan muara sungai Bodri selama 10 tahun (2009-2019) pada saat musim Timur. Penelitian ini menggunakan data morfologi, pasang surut, angin, gelombang, arus sejajar pantai, sampel sedimen gosong, dan material padatan tersuspensi. Metode penelitian yang digunakan adalah metode pendekatan studi kasus dan untuk pentuan titik sampling menggunakan metode purposive sampling serta dianalisis secara kuantitatif. Hasil penelitian dibagi menjadi 3 daerah yaitu daerah Timur muara, depan muara dan Barat muara. Besar arus sejajar pantai di daerah Timur muara yaitu $1,020 \mathrm{~m} / \mathrm{s}$, pada daerah depan muara terjadi arus sejajar pantai sebesar 1,243 $\mathrm{m} / \mathrm{s}$ dan pada daerah Barat muara terjadi arus sejajar pantai sebesar $0,856 \mathrm{~m} / \mathrm{s}$. Transpor sedimen terjadi pada bagian Timur muara dengan arah dari Tenggara ke arah Utara sebesar 979.954,903 $\mathrm{m}^{3} /$ tahun, kemudian di depan muara sungai arah berbelok ke Barat sebesar 1.131.864,393 $\mathrm{m}^{3} /$ tahun, selanjutnya di Barat muara sungai berbelok dari arah Utara ke arah Barat Daya sebesar 432.014,433 $\mathrm{m}^{3} /$ tahun. Hasil data konsentrasi sedimen tersuspensi menunjukkan bahwa daerah Timur memiliki nilai konsentrasi paling besar kemudian daerah Barat memiliki nilai konsentrasi terendah. Penelitian ini diharapkan dapat bermanfaat dalam perencanaan pencegahan abrasi dan akresi di perairan muara sungai Bodri.
\end{abstract}

Kata kunci : Transpor Sedimen, Arus Sejajar Pantai, Sungai Bodri

\begin{abstract}
The beach will continue to change its shape to adjust its dynamic balance conditions, the process can result in accretion or abrasion. The changing morphology of the coast also occurs in the Bodri river estuary waters. This cannot be separated from the influence of waves, longshore currents, and sediment movements that occur. This change will affect the activities of the population, especially fishermen who have difficulty in and out of the Bodri river estuary. The purpose of this study was to determine sediment transport caused by longshore currents in the Bodri river estuary waters for 10 years (2009-2019) during the East season. This study uses morphological data, tides, winds, waves, longshore currents, scorched sediment samples, and suspended solids material. The research method used is the case study approach and for the determination of sampling points using purposive sampling method and analyzed quantitatively. The results of the study were divided into 3 regions, namely the Eastern estuary, the mouth of the estuary, and the West estuary. Large inshore current in the East area is $1.020 \mathrm{~m} / \mathrm{s}$, in front of the mouth of the estuary there is a beachside current of $1.243 \mathrm{~m}$ $/ \mathrm{s}$ and in the Eastern area a longshore current occurs at $0.856 \mathrm{~m} / \mathrm{s}$. Sediment transport occurs in the eastern part of the river estuary with a direction from Southeast to North at 979,954,903 m3 / year, then in front of the river estuary to turn West at 1,131,864,393 $\mathrm{m} 3$ / year, then in the West the river estuary turns from North to Southwestern direction of 432,014,433 m3 / year. The results of suspended sediment concentration data show that the East region has the highest concentration value, then the West region has the lowest concentration value. This research is expected to be useful in planning the prevention of abrasion and accretion in the Bodri river estuary waters.
\end{abstract}

Keywords : Sediment Transport, Longshore Current, Bodri River 


\section{PENDAHULUAN}

Pantai merupakan daerah yang mudah mengalami perubahan secara fisik akibat pengaruh laut seperti gelombang, arus dan pasang surut. Gelombang merupakan salah satu faktor oseanografi yang berpengaruh terhadap transport sedimen (Triatmodjo, 1999). Widjojo (2010) mengatakan bahwa gelombang yang menuju pantai akan pecah di perairan dangkal menimbulkan arus sejajar pantai. Gelombang yang pecah ini akan mengaduk sedimen pantai, sehingga terjadi perpindahan sedimen dasar. Perpindahan sedimen yang terusmenerus akan menyebabkan sedimentasi di suatu bagian pantai sekaligus menyebabkan abrasi pada bagian lain di perairan (Triatmodjo, 1999).

Kendal mempunyai satu sungai besar yang terletak di Kecamatan Patebon, Kabupaten Kendal yaitu sungai Bodri (BAPPEDA Kendal, 2012). Sungai Bodri terus mengalami perubahan bentuk dan luas terutama pada bagian muara sungainya. Tahun 1864 - 1910 delta Muara Sungai Bodri mengalami pertambahan luas sebesar $0.16 \mathrm{~km}^{2} /$ tahun dengan delta berbentuk menjorok ke laut, sedangkan pada periode 1910 - 1946 mengalami pertambahan luas sebesar $0.402 \mathrm{~km}^{2} /$ tahun dengan bentuk delta muara melebar ke sepanjang pantai (Tjia et al., 1968 dalam Atmodjo, 2010). Bentuk muara yang selalu bertambah tiap tahunnya membuktikan bahwa terjadi akresi dan pendangkalan di Muara Sungai Bodri, proses ini dapat diakibatkan oleh arus dan gelombang. Menurut Atmodjo (2010), energi gelombang di perairan Muara Sungai Bodri cukup tinggi sehingga tiap tahunnya sedimentasi di depan muara sungai semakin bertambah. Proses tersebut dapat memberikan dampak terhadap aktivitas penduduk terutama nelayan yang terganggu dalam akses keluar masuk Sungai Bodri.

Perubahan morfologi yang terjadi dapat merubah arah penjalaran gelombang dan mempengaruhi besar nilai arus sejajar pantai serta transpor sedimennya. Penelitian ini bertujuan untuk mengkaji mengenai arus sejajar pantai (longshore current) yang dibangkitkan gelombang di Perairan Muara Sungai Bodri. Arus sejar pantai tersebut mampu menimbulkan transpor sedimen di lokasi penelitian.

\section{MATERI DAN METODE}

Materi penelitian yang digunakan meliputi pasang surut, material padatan tersuspensi, sedimen gosong, gelombang, angin, dan topografi dasar perairan. Penelitian dilakukan pada bulan Agustus 2019 hingga bulan Maret 2020 yang meliputi pengukuran dan pengambilan sampel di lapangan, pengolahan data di laboratorium, analisis data hasil penelitian dan penyusunan laporan penelitian. Lokasi penelitian secara geografis terletak pada koordinat 6 ${ }^{\circ} 49^{\prime} 14.86^{\prime}$ ' $6^{\circ} 51$ '22.54' Lintang Selatan dan $110^{\circ} 9$ '26.48' $-110^{\circ} 11^{\prime} 32.71^{\prime}$ ' Bujur Timur. Peta penelitian ditunjukan pada Gambar 1.
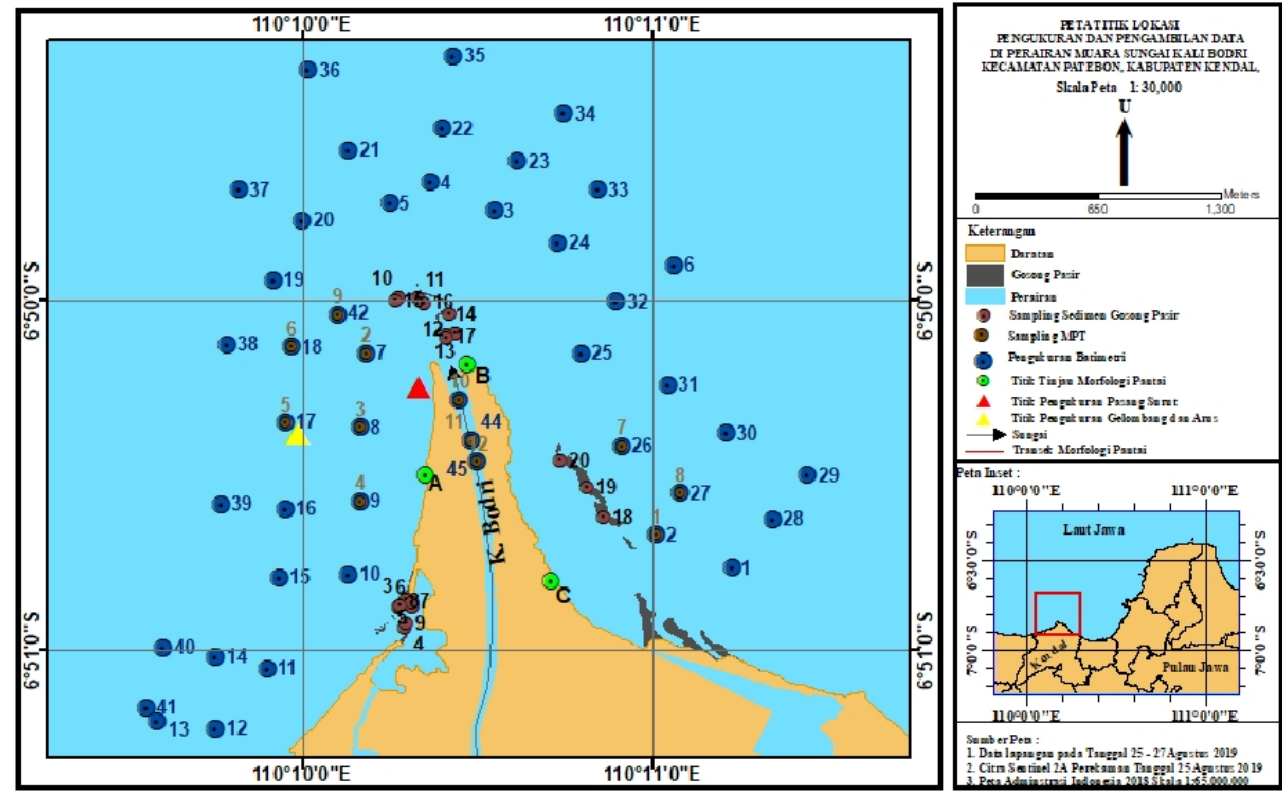


\section{Gambar 1.Peta Lokasi Penelitian}

Metode yang digunakan dalam penelitian ini adalah metode studi kasus. Metode ini digunakan untuk mengkaji lebih lanjut latar belakang keadaan saat ini pada suatu objek (Suryabrata, 2010). Analisis data dilakukan secara kuantitatif artinya analisa bersifat konkret, objektif, terukur, rasional dan sistematis menggunakan data berupa angka (Sugiyono, 2009). Hal ini dikarenakan pada penelitian ini data yang digunakan berupa angka.

\section{Pasang Surut}

Pengukuran pasang surut lapangan dilakukan selama 3 x 24 jam dalam interval 1 jam menggunakan palem pasang surut. Sedangkan data pasang surut sekunder diperoleh dari pengunduhan http://tides.big.go.id, yang berupa nilai elevasi setiap 1 jam selama satu bulan (Agustus 2019). Verifikasi kedua data dihitung dengan metode RMSE (Root Mean Square Error). Data pasang surut sekunder diolah menggunakan metode Admiralty untuk memperoleh komponen pasang surut dan tipe pasang surut.

\section{Morfologi dan Sedimen Gosong}

Pengambilan data batimetri dilakukan pada 42 titik dengan pola acak dan menyebar di perairan Muara Sungai Bodri. Hal ini bertujuan untuk memperoleh tingkat presisi penelitian yang tinggi. Nilai kedalaman lapangan yang didapat dikoreksi dengan nilai muka air laut rata - rata (MSL).

Pemilihan transek morfologi sebanyak 3 titik tinjau antara lain titik A pada bagian Barat muara sungai Bodri, titik B pada bagian depan mulut muara sungai Bodri dan titik $\mathrm{C}$ pada bagian Timur muara sungai Bodri. Hal ini dilakukan agar diketahui kemiringan dasar pantai di setiap bagian sekitar muara dengan karakteristik pantai yang berbeda.

Pentuan titik sampling sedimen gosong menggunakan metode purposive sampling yaitu penentuan titik pengambilan sampel dengan pertimbangan mewakili keadaan seluruh daerah penelitian (Yudowati, 2012). Titik lokasi sampel sedimen pada penelitian ini berjumlah 20 titik dengan sebaran lokasi diambil secara menyebar sepanjang gosong mulai dari gosong daerah timur hingga barat muara sungai. Sampel sedimen gosong dari lokasi penelitian dianalisa ukuran butirnya dengan menggunakan metode analisa granulometri, kemudian dilakukan pengelompokkan ukuran butir dengan skala Wentworth dan penamaan sedimen menggunakan segitiga shepard.

\section{Gelombang}

Penentuan titik pengukuran dipilih dengan menggunakan metode area sampling yang digunakan untuk menentukan sampel apabila objek yang akan diteliti atau sumber datanya sangat luas (Sugiyono, 2009). Penelitian gelombang dilakukan pada satu titik, yang terletak pada koordinat $06^{\circ} 50^{\prime} 22.8^{\prime \prime} \mathrm{LS}-$ $110^{\circ} 09^{\prime} 59.2^{\prime \prime}$ BT dengan kedalaman 6 meter. Pengambilan data gelombang dilakukan dengan perekaman menggunakan instrumen ADCP (Accoustic Doppler Current Profiler) selama 3 hari pada tanggal 25-27 Agustus 2019. Pemasangan ADCP disesuaikan dengan pertimbangan bahwa stasiun pengukuran mewakili pergerakan gelombang di perairan Muara Sungai Bodri dan tidak pada daerah gelombang pecah.

Peramalan gelombang dari data angin musim timur selama 10 tahun dilakukan dengan menggunakan metode Svendrup-Munk-Bretcheider (SMB) (CERC, 1984). Perhitungan Verifikasi antara data lapangan dan peramlan menggunakan koreksi nilai Root Mean Square Error (RMSE).

Data gelombang representative (Hs) dan (Ts) yang didapat digunakan untuk menghitung nilai gelombang pecah. Data gelombang pecah kemudian diolah untuk memperoleh nilai kecepatan arus sepanjang pantai.

\section{Material Padatan Tersuspensi (MPT)}

Data MPT di perairan muara sungai Bodri diambil menggunakan botol sampel dengan metode pengambilan data purposive sampling pada 12 titik lokasi sampel dengan pola titik sampling 
menyebar agar diketahui perbedaan konsentrasi sedimen tersuspensi pada tiap titik tinjau morfologi dan hasil yang didapat memiliki tingkat akurasi tinggi. Kemudian Sampel MPT diolah di laboratorium dengan menggunakan Vacuum Pump. Data hasil pengolahan kemudian dihitung untuk mendapatkan nilai konsentrasi MPT menggunakan persamaan Alerts dan Santika (1984) dalam Riniatsih (2015) :

$$
M P T=\frac{(a-b) 100}{c} .
$$

Keterangan :

$a=$ berat residu dan kertas saring setelah pemanasan ( $\mathrm{mg}$ )

$b=$ berat kering kertas saring (mg)

$c=$ volume sampel air $(\mathrm{ml})$

\section{Transpor Sedimen}

Cara memprediksi transpor sedimen sepanjang pantai dengan menggunakan rumus empiris yang didasarkan pada kondisi gelombang didaerah yang ditinjau. Rumus empiris ini merupkan hubungan sederhana antara transpor sedimen dengan komponen fluks energy gelombang sepnjang pantai dalam bentuk persamaan:

$$
\mathrm{P}_{1}=\frac{\rho g}{8} \mathrm{H}_{\mathrm{b}}^{2} \mathrm{C}_{\mathrm{b}} \sin \alpha_{\mathrm{b}} \cos \alpha_{\mathrm{b}}
$$

CERC (1984) memberikan hubungan untuk Qs dengan satuan m3/tahun yaitu:

$$
\mathrm{Qs}=1290 \mathrm{P} 1
$$

Untuk Qs dengan satuan $\mathrm{m} 3 /$ hari sebagai berikut:

$$
\mathrm{Qs}=3,534 \mathrm{P} 1
$$

Keterangan:

Qs : angkutan sedimen sepanjang pantai (m3/hari)

$\mathrm{P} 1$ : komponen fluks energi gelombang sepanjang pantai pada saat pecah $(\mathrm{Nm} / \mathrm{d} / \mathrm{m})$

$\rho$ : rapat massa air laut $(\mathrm{kg} / \mathrm{m} 3)$

$\mathrm{Hb}$ : tinggi gelombang pecah $(\mathrm{m})$

$\mathrm{Cb}:$ cepat rambat gelomang pecah $(\mathrm{m} / \mathrm{d}): ; \mathrm{g} \mathrm{db}$

$\alpha \mathrm{b}$ : sudut datang gelombang pecah

$\mathrm{K}, \mathrm{n}:$ konstanta

\section{HASIL DAN PEMBAHASAN}

\section{Pasang Surut}

Hasil pengolahan data pasang surut dengan metode Admiralty diperoleh nilai elevasi muka air laut seperti seperti MSL sebesar 0,87 m, Zo sebesar 0,63 m, HHWL sebesar 1,51 m, MHWL sebesar $0,78 \mathrm{~m}$, LLWL sebesar $0,24 \mathrm{~m}$, dan MLWL sebesar $0,45 \mathrm{~m}$. Tipe pasang surut di perairan Muara Sungai Bodri adalah campuran condong harian tunggal dengan pola lembah dan puncak yang terjadi 2 kali dalam sehari namun lebih condong terjadi 1 kali dalam sehari dengan nilai formzahl (F) sebesar 2,283. Hal ini didukung dengan pernyataan Srijati et al. (2017) bahwa pasang surut perairan Kendal memiliki tipe pasang surut campuran (dominan tunggal) dengan nilai formzahl sebesar 1,57. Kondisi pasang surut pada lokasi penelitian yang tidak signifikan berpotensi kecil untuk memindahkan partikel sedimen sehingga tidak begitu mempengaruhi jenis dan sebaran ukuran butir sedimen di Perairan Muara Sungai Bodri

\section{Morfologi dan Sebaran Sedimen}

Hasil penelitian diketahui bahwa lokasi penelitian memiliki kedalaman perairan $0,1-13 \mathrm{~m}$. Pada peta batimetri (Gambar 2), daerah Timur muara sungai memiliki nilai kelerengan yang landai, hal ini ditunjukkan dengan bentuk kontur kedalaman yang memiliki jarak lebih besar pada Timur muara sungai. Selain itu juga didukung dengan hasil penampang melintang morfologi perairan muara sungai Bodri (Gambar 3) yang memiliki nilai kelerengan sebesar 0,2\%. Daerah Barat muara memiliki nilai kelerengan sebesar $0,8 \%$ yang menandakan pada daerah tersebut memiliki dasar perairan yang 
lebih curam dibandingkan kedua daerah lainnya. Berdasarkan nilai kelerengan tersebut diketahui bahwa kelerengan dasar laut perairan muara sungai Bodri sangat landai (Gambar 5). Hal ini didukung oleh pernyataan Supriyadi et al. (2014) yang mengatakan bahwa pantai utara Jawa cenderung bertipe kelerengan landai yaitu antara $0-2 \%$. Dikatakan juga bahwa kelerengan dasar laut yang landai disebabkan oleh beberapa faktor seperti kondisi perairan yang tenang, tinggi gelombang yang kecil dan jenis sedimen yang terbentuk. Energi gelombang yang terjadi di perairan muara sungai Bodri relatif kecil sehingga morfologi pantai yang terbentuk adalah landai. Mahfudz (2012) dalam Kalay et al. (2014) menambahkan bahwa morfologi pantai sangat ditentukan oleh intensitas, frekuensi dan kekuatan energi yang diterima pantai tersebut, daerah berenergi rendah biasanya memiliki kelerengan yang landai.

Berdasarkan peta sebaran gosong (Gambar 3), terdapat gosong pasir pada daerah Timur, depan, dan Barat muara sungai Bodri. Pada bagian Timur muara sungai terdapat gosong yang berbentuk datar memanjang sejajar dengan garis pantai. Triatmodjo (1999) menyebutkan bahwa sedimen gosong pasir sejajar pantai menandakan bahwa sedimentasi di daerah tersebut lebih dominan dipengaruhi oleh energi gelombang. Gosong pasir pada daerah depan muara sungai terbentuk akibat adanya energi dari laut dan sungai. Hal ini diperkuat dengan pernyataan Gemilang et al. (2018) bahwa disaat kondisi pasang arus sungai yang bertemu dengan air laut akan melemah dibagian muara sehingga endapan sungai laut bercampur dengan fraksi sedimen kasar dan lama kelamaan membentuk gosong. Gosong tersebut memiliki bentuk melengkung dengan cembung ke arah laut. Triatmodjo (1999) mengatakan bahwa debit sungai dapat mengikis gosong bagian dalam sehingga bagian dalamnya berbentuk cekung dan air sungai keluar melalui bagian kanan dan kiri gosong pasir.
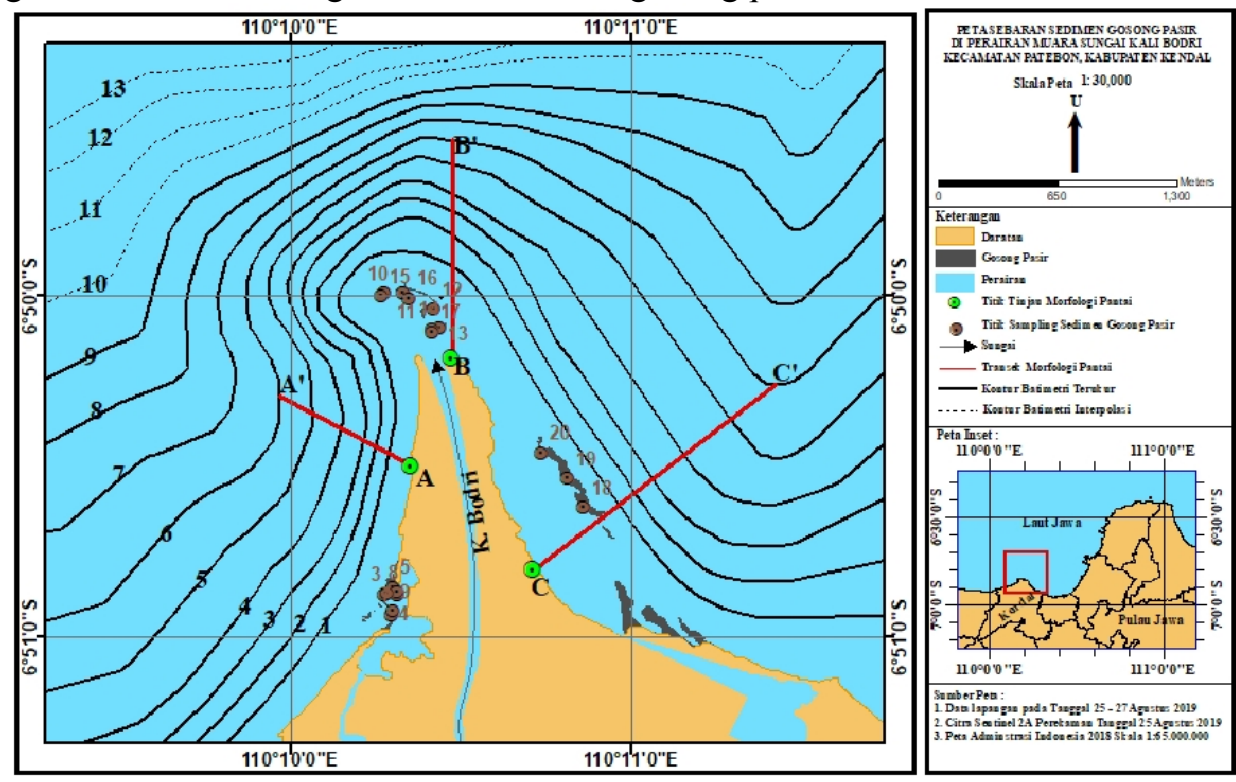

Gambar 2. Peta Batimetri dan Sebaran Sedimen Gosong Perairan Muara Sungai Bodri

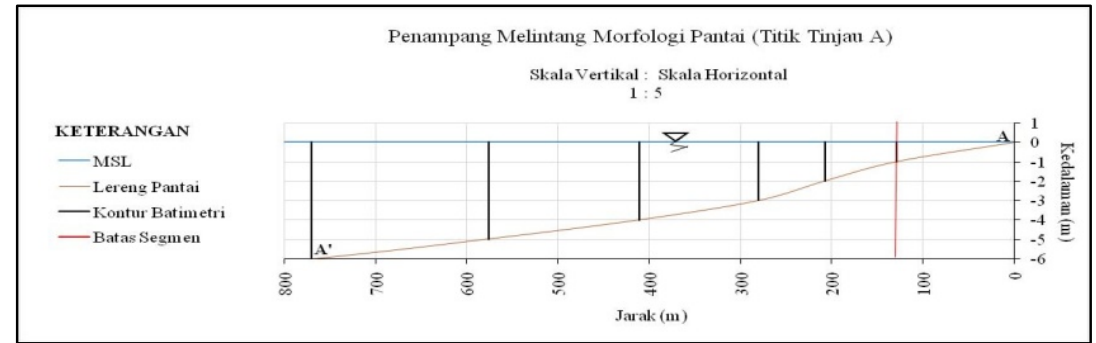

Gambar 3. Penampang Melintang Morfologi Pantai Daerah Barat Muara Sungai 


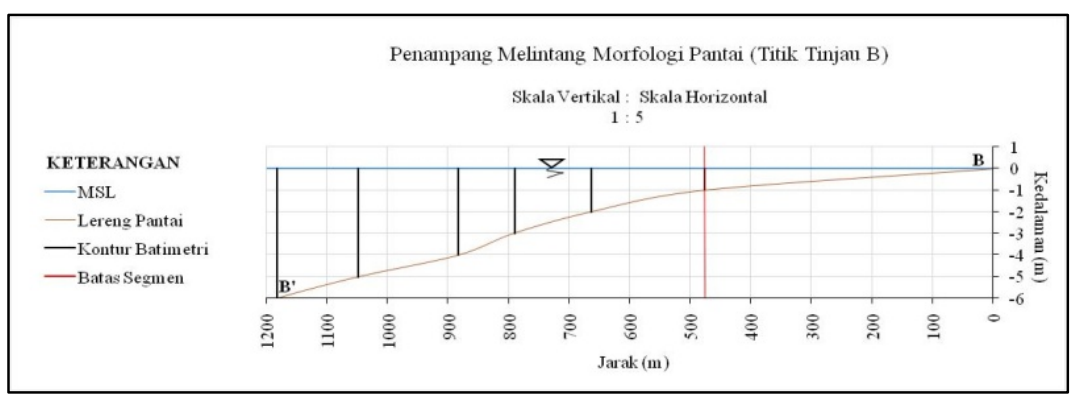

Gambar 4. Penampang Melintang Morfologi Pantai Daerah Depan Mulut Muara Sungai

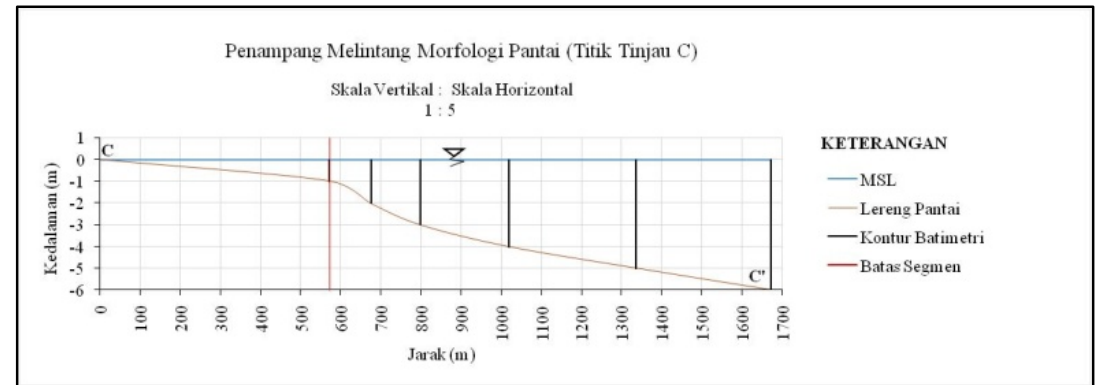

Gambar 5. Penampang Melintang Morfologi Pantai Daerah Barat Muara Sungai

\section{Material Padatan Tersuspensi}

Nilai konsentrasi MPT yang didapat berkisar antara 0,035 - 0,5 g/L. Daerah Timur muara sungai memiliki konsentrasi material padatan tersuspensi yang tinggi yaitu sebesar $0,4-0,5 \mathrm{~g} / \mathrm{L}$. Daerah depan muara memiliki nilai konsentarsi sedimen tersuspensi antara $0,15-0,3 \mathrm{~g} / \mathrm{L}$. Konsentrasi sedimen tersuspensi pada daerah Timur dan depan muara relatif besar dibandingkan daerah Barat muara sungai (Gambar 6). Hal tersebut dikarenakan daerah Timur dan depan muara cenderung lebih landai dan dangkal. Daerah yang lebih dangkal memiliki nilai gelombang pecah dan kecepatan arus sejajar pantai yang besar dibandingkan dengan perairan yang lebih dalam, hal ini mengakibatkan nilai konsentrasi sedimen tersuspensi pada daerah dangkal menjadi besar. Pernyataan tersebut diperkuat oleh Sarjono (2009) yang mengatakan bahwa muara sungai yang dipengaruhi oleh arus tinggi menyebabkan terjadi proses pengadukan sedimen dasar perairan yang juga berperan dalam meningkatkan nilai kekeruhan perairan. Daerah depan muara mendapat masukkan debit sedimen ratarata dari sungai Bodri sebesar $0,0217 \mathrm{~m}^{3} /$ hari dengan nilai konsentrasi MPT berkisar antara $0,053-$ $0,077 \mathrm{~g} / \mathrm{L}$. Damayanti et al. (2013) mengatakan bahwa muara sungai merupakan perantara terbawanya MPT dari sungai ke laut lepas yang ditunjukkan dengan tingginya konsentrasi MPT dimuara sungai. Sedangkan pada Barat muara sungai memiliki nilai konsentarsi sedimen tersuspensi antara 0,035 $0,09 \mathrm{~g} / \mathrm{L}$ dengan kondisi kemiringan dasar laut lebih curam dibandingkan daerah lainnya. 


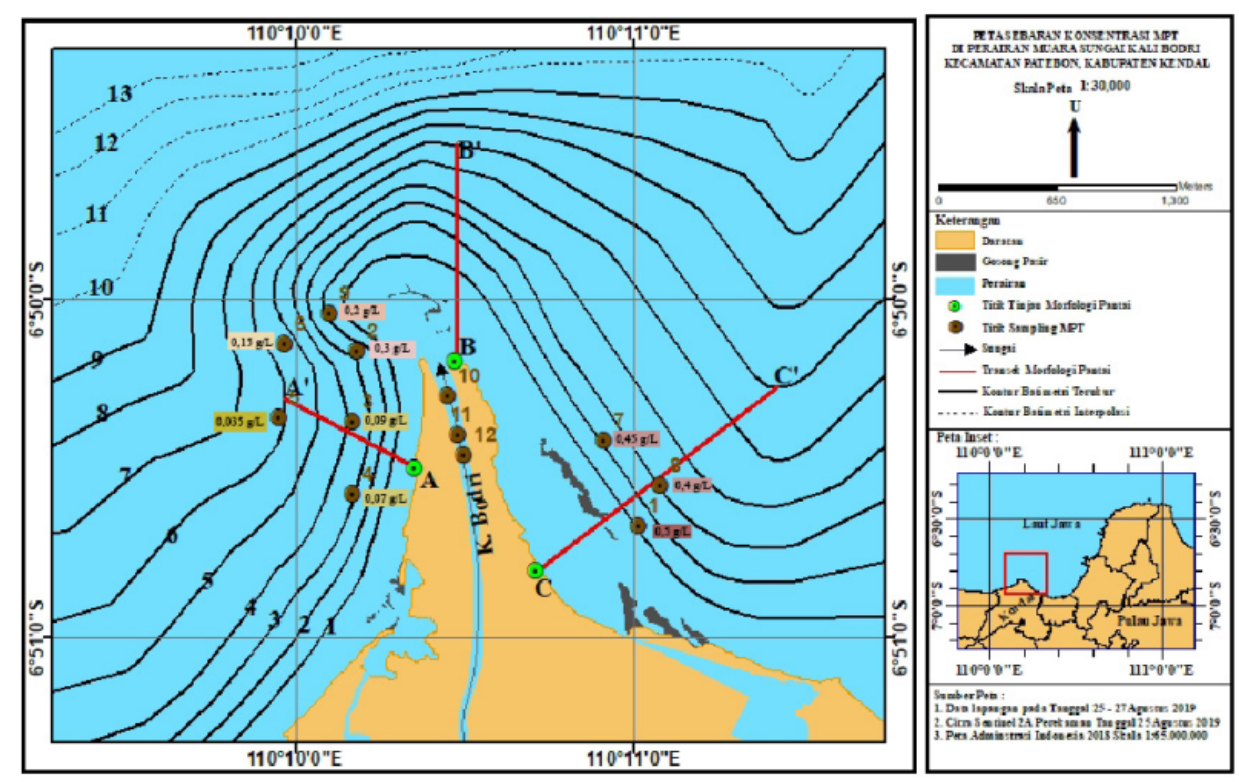

Gambar 6. Sebaran Konsentrasi Material Padatan Tersuspensi

\section{Mekanisme Transpor Sedimen}

Pengukuran gelombang secara langsung dengan menggunakan ADCP menunjukan tinggi $(H)$ dan periode $(T)$ gelombang. Berdasarkan data tersebut, diperoleh nilai $H$ maksimum yaitu $0,163 \mathrm{~m}$ dan $H$ minimum yaitu $0,006 \mathrm{~m}$. Berdasarkan perhitungan didapatkan $H$ signifikan $0,123 \mathrm{~m}$ dan $H$ rerata $0,102 \mathrm{~m}$. Nilai $T$ maksimum saat pengambilan data adalah 6,5 detik dan $T$ minimum adalah 2.1 detik. Berdasarkan perhitungan, didapatkan $T$ signifikan sebesar 4,66 detik dan $T$ rerata sebesar 3,1 detik. Nilai fetch efektif untuk pembangkit gelombang di Perairan Muara Sungai Bodri adalah angin utara sebesar $175,713 \mathrm{~km}$ dan angin timur laut sebesar 129,456 km. Kemudian didapatkan peramalan gelombang pada musim timur 10 tahun (2009 -2019) dengan metode SMB didapatkan tinggi gelombang signifikan (Hs) sebesar 0,732 $\mathrm{m}$ dan periode gelombang signifikan (Ts) sebesar 4,575 detik, secara lengkap disajikan pada tabel 2. Gelombang di Perairan Muara Sungai Bodri merupakan gelombang yang dibangkitkan oleh angin karena memiliki periode gelombang antara $1-15$ detik (Triatmodjo, 1999). Hal ini diperkuat oleh pernyataan Handoyo dan Suryoputro (2015) bahwa tinggi gelombang di perairan pantai Kendal dapat dikategorikan kecil hal ini dimungkinkan karena angin yang berhembus yang relatif kecil.

Titik A di daerah barat muara sungi memiliki nilai kelerengan (m) $0.8 \%$, tinggi gelombang pecah $(\mathrm{Hb})$ sebesar $0.565 \mathrm{~m}$ dengan sudut gelombang pecah $(\alpha \mathrm{b})$ sebesar $19,99^{\circ}$. Titik B di depan muara sungai memiliki nilai kelerengan $(\mathrm{m}) 0.2 \%$, tinggi gelombang pecah $(\mathrm{Hb})$ sebesar $0.764 \mathrm{~m}$ dengan sudut gelombang pecah $(\alpha \mathrm{b})$ sebesar $25,45^{\circ}$. Titik $\mathrm{C}$ di daerah timur muara sungai memiliki nilai kelerengan $(\mathrm{m}) 0.2 \%$, tinggi gelombang pecah $(\mathrm{Hb})$ sebesar $0.772 \mathrm{~m}$ dengan sudut gelombang pecah $(\alpha b)$ sebesar $20,46^{\circ}$. Berdasarkan hasil perhitungan gelombang pecah diketahui bahwa daerah timur dan depan muara memiliki nilai tinggi gelombang pecah yang besar, hal ini karena angin dominan berasal dari timur laut sehingga kecepatan angin tidak terhalang apapun. Pendangkalan perairan juga dapat mempengaruhi tinggi gelombang pecah dimana pada daerah timur dan depan muara sungai di kedalam $1 \mathrm{~m}$ memiliki kemiringan yang kecil dibandingan pada barat muara sungai. Hal ini sesuai dengan pernyataan Sakka et al. (2010) yang menjelaskan bahwa pantai dengan kelerengan landai memiliki gelombang yang lebih tinggi daripada pantai yang curam. Gelombang datang dari arah timur laut menuju daerah timur dan mulut muara bergerak dengan cepat, pada saat akan pecah gelombang menabrak dasar perairan sehingga gelombang mengalami perubahan bentuk dan ketinggian puncak gelombang akan bertambah pada saat pecah. Siregar et al. (2014) menyatakan bahwa gelombang yang datang menuju pantai akan mengalami refraksi yaitu perubahan bentuk 
sebagai akibat adanya perubahan kedalaman perairan. Sedangkan pada daerah barat muara sungai memiliki nilai tinggi gelombang pecah terkecil karena daerah tersebut terlindung oleh gosong pasir didepan muara sehingga gelombang yang ada pada daerah ini tidak sebesar daerah lainnya. Hal ini diperkuat pernyataan Satriadi dan Sugeng (2004) bahwa Pengaruh gelombang yang kecil ini akibat adanya gosong pasir di depan muara sungai yang menghalangi pengaruh gelombang secara langsung.

Berdasarkan Peta arah datang gelombang dan arus sejajar pantai (longshore current) pada Gambar 7, diketahui bahwa arus sejajar pantai bergerak dari tenggara menuju utara dengan kecepatan $1,020 \mathrm{~m} /$ det mengangkut sedimen sebesar $2.684 .621 \mathrm{~m}^{3} /$ hari atau $979.954,903 \mathrm{~m}^{3} /$ tahun. Arah berbelok ke Utara dikarenakan adanya pembelokan arah gelombang dari laut lepas. Hal ini didukung oleh pernyatan Sakka et al, (2010) yang menyatakan bahwa perubahan arah datang gelombang terjadi saat gelombang sudah dekat pantai akibat adanya perbedaan cepat rambat gelombang dari refraksi. Perbedaan cepat rambat gelombang dapat membentuk sudut terhadap garis pantai. Arus yang bergerak sejajar pantai pada daerah Timur mampu mengangkut sedimen dan mengendapkan pada daerah tersebut.

Sedimen yang tidak terendapkan pada daerah timur muara sungai akan terbawa arus kearah Utara dan menuju daerah depan muara. Arus sejajar pantai sebesar $1,243 \mathrm{~m} /$ det pada daerah depan muara akan berbelok ke arah barat akibat bertabrakan dengan gelombang dengan mengangkut sedimen sebesar 3.100,782 $\mathrm{m}^{3} /$ hari atau $1.131 .864,393 \mathrm{~m}^{3} /$ tahun. Transpor sedimen pada daerah ini memiliki nilai paling besar dibandingkan daerah lainnya. Hal tersebut dikarenakan ada suplai sedimen dari daratan yang dibawa oleh aliran sungai denga nilai debit sedimen rata-rata sebesar $0,0217 \mathrm{~m}^{3} /$ hari. Aliran sungai yang bergerak menuju laut lepas mampu mengikis bagian dalam gosong pasir yang berada di depan muara sungai, sehingga bentuk gosong pasir menjadi berbentuk cekung pada bagian dalamnya. Hal ini sesuai dengan pernyataan Triatmodjo (1999), bahwa debit sungai yang besar akan mengikis gosong bagian dalam sehingga bagian dalamnya berbentuk cekung dan air sungai keluar melalui bagian kanan dan kiri gosong pasir.

Pada bagian Barat muara, arus sejajar pantai bergerak menuju ke arah Barat Daya. Hal ini sesuai dengan pernyataan Triatmodjo (1999) dimana arah arus sejajar pantai sama dengan arah gelombang datang. Arus sejajar pantai pada daerah ini bergerak dengan kecepatan $0,856 \mathrm{~m} /$ det mengangkut sedimen sebesar $1.183,519 \mathrm{~m}^{3} /$ hari atau $432.014,433 \mathrm{~m}^{3} /$ tahun. Arah datang gelombang pada daerah Barat hampir tegak lurus dengan garis pantai, sehingga kecepatan arus sejajar pantai cenderung lebih kecil. Hal ini yang mengakibatkan nilai transpor sedimen pada timur muara lebih kecil dibanding bagian Timur dan depan muara sungai. Menurut Triatmodjo (1999), arah datang gelombang dapat mempengaruhi energi gelombang dan kecepatan arus sepanjang pantai. Ketika arah datang gelombang tegak lurus dengan garis pantai, maka energi gelombang yang bekerja lebih maksimal dalam melakukan abrasi. Sedangkan untuk arus sejajar pantai, kecepatannya akan melemah ketika arah datangnya hampir tegak lurus dengan dengan arah garis pantai. 

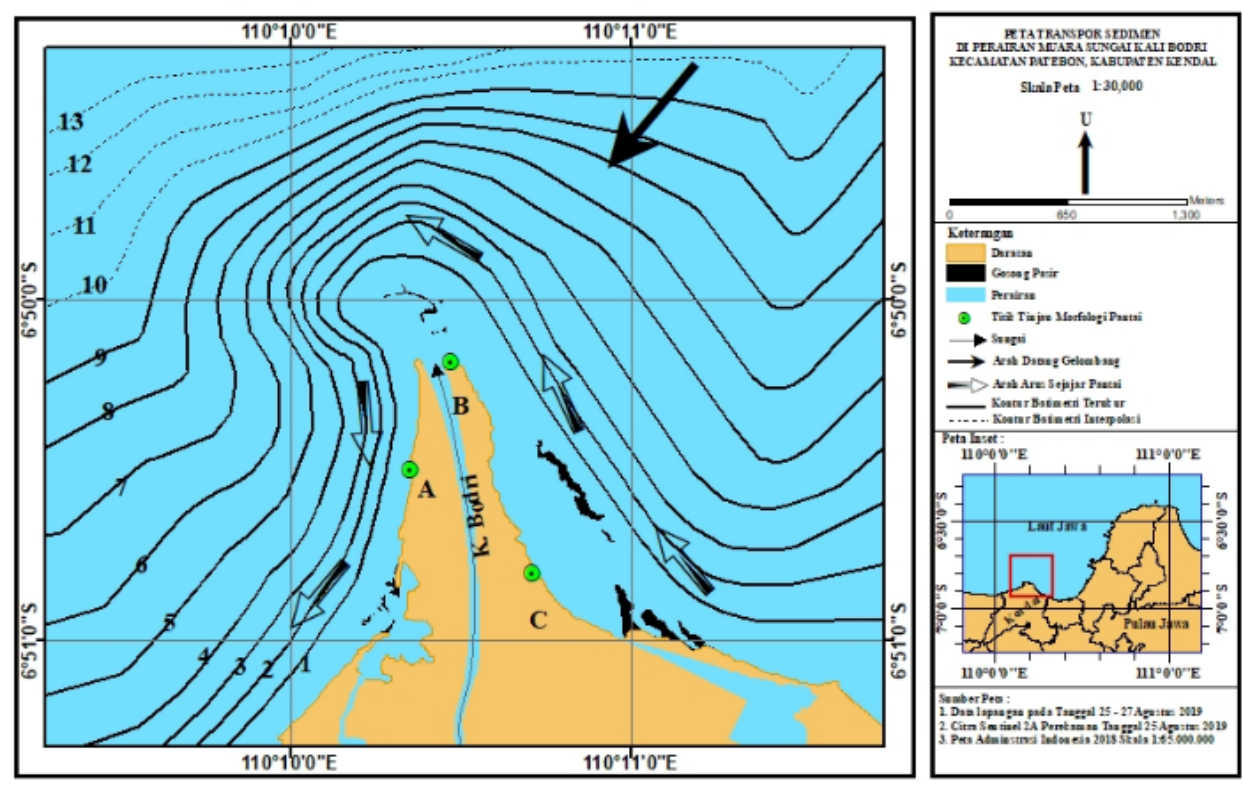

Gambar 7. Arah Datang Gelombang dan Arus Sejajar Pantai

\section{KESIMPULAN}

Longshore current terjadi berawal dari bagian Timur muara sungai kali Bodri dengan arah dari Tenggara ke arah Utara dengan kecepatan $1,020 \mathrm{~m} /$ det, kemudian di depan muara sungai arahnya berbelok ke Barat dengan kecepatan sebesar $1,243 \mathrm{~m} / \mathrm{det}$, selanjutnya pada Barat muara arah bergerak dari Utara ke Barat Daya dengan kecepatan sebesar 0,856 m/det. Besar arus sejajar pantai berpengaruh terhadap kecepatan transpor sedimen. Nilai transpor sedimen yang terjadi pada daerah Timur muara sungai adalah 979.954,903 $\mathrm{m}^{3} /$ tahun. Hasil transpor sedimen di depan muara sungai sebesar $1.131 .864,393 \mathrm{~m}^{3} /$ tahun dan mendapat suplai sedimen dari aliran sungai sebesar $0,0217 \mathrm{~m}^{3} /$ hari. Hasil transpor sedimen yang terjadi pada bagian Barat muara sungai adalah $432.014,433 \mathrm{~m}^{3} /$ tahun .

\section{DAFTAR PUSTAKA}

Atmodjo, W. 2010. Sebaran Sedimen di Perairan Delta Sungai Bodri, Kendal, Jawa Tengah. Jurnal Ilmu Kelautan., 15(1): 53 - 58.

CERC (Coastal Engineering Research Center). 1984. Shore Protection Manual Volume I, Fourth Edition. Washington: U.S. Army Coastal Engineering Research Center, Washington D.C, 337 hlm.

Damayanti, R., Hariadi dan W. Atmodjo. 2013. Pengaruh Arus Terhadap Sebaran Muatan Padatan Tersuspensi di Pantai Slamaran Pekalongan. Jurnal Oseanografi., 2(1): 128 - 142.

Dyer, K.R. 1986. Coastal and Estuary Sediment Dynamic. John Willey \& Sons. Chichester, $342 \mathrm{hlm}$.

BAPPEDA Kendal. 2012. Pengembangan Sistem Informasi Profil Daerah Kabupaten Kendal Tahun 2012. BAPPEDA. Kendal.

Gemilang, W.A., U.J. Wisha., G.A. Rahmawan., dan R. Dhiauddin. 2018. Karakteristik Sebaran Sedimen Pantai Utara Jawa Studi Kasus: Kecamatan Brebes Jawa Tengah. Jurnal Kelautan Nasional., 13(2): $65-74$.

Handoyo, G dan Agus A.D Suryoputro. 2015. Kondisi Arus dan Gelombang pada Berbagai Kondisi Morfologi Pantai di Perairan Pantai Kendal Provinsi Jawa Tengah. Jurnal Kelautan Tropis., 18(1): $33-37$. 
Kalay, D. E., J. J. Wattimury dan K. Manilet. 2014. Kemiringan Pantai dan Distribusi Sedimen Pantai Di Pesisir Utara Pulau Ambon. Jurnal Triton, 10(2):91-103.

Riniatsih, I. 2015.Distribusi Muatan Padatan Tersuspensi (MPT) di Padang Lamun di Perairan Teluk Awur dan Pantai Prawean Jepara. Jurnal Kelautan Tropis., 18(3): 121 - 126.

Sakka., M. Purba., I.W Nurjaya., H. Pawitan dan V.P Siregar. 2010. Transpormasi Gelombang di Sepanjang Pantai Delta Sungai Jeneberang, Makassar. Jurnal Ilmu Kelautan dan Perikanan., 20(2): $36-48$.

Sarjono, A. 2009. Analisis Kandungan Logam Berat Cd, Pb, dan $\mathrm{Hg}$ pada Air dan Sedimen di Perairan Kamal Muara, Jakarta Utara. Departemen Manajemen Sumberdaya Perairan. Fakultas Perikanan dan Ilmu Kelautan. Institut Pertanian Bogor, Bogor.

Satriadi, A.,Sugeng, W. 2004. Distribusi Muatan Padatan Tersuspensi di Muara Sungai Bodri, Kabupaten Kendal. Jurnal Ilmu Kelautan.,9(2):101-107

Srijati, S., B. Rochaddi dan S. Widada. 2017. Analisis Laju Sedimentasi di Perairan Muara Sungai Waridin Kabupaten Kendal. Jurnal Oseanografi. 6(1): 246 - 253.

Sugiyono. 2009. Metode Penelitian Kuantitatif Kualitatif dan R\&D. CV Alfabeta. Bandung.

Supriyadi, A., S. Widada dan H. Setiyono. 2014. Pemetaan Batimetri untuk Alur Pelayaran Pelabuhan Penyeberangan Mororejo Kabupaten Kendal. Jurnal Oseanografi., 3(2): 284 - 293.

Suryabrata. 2010. Metodologi Penelitian. Jakarta. Rajawali Pers.

Triatmodjo, B. 1999. Teknik Pantai. Beta Offset, Yogyakarta, $397 \mathrm{hlm}$.

Widjojo, S. JB. 2010. Transportasi Sedimen oleh Kombinasi Aliran Permanen Beraturan dan Gelombang Seragam. Media Teknik Sipil. ISSN 1412-0976.UNS. Surakarta.

Yudowati, S.O., Warsito, A., Sri Y.W. 2012. Studi Transpor Sedimen Di Pantai Slamaran Pekalongan. FPIK Undip Semarang, J-Oce 197-196. 